UDC 657.24

JEL M41

DOI 10.26906/EiR.2021.1(80).2245

\title{
DOCUMENTING THE PURCHASE OF FUELS AND LUBRICANTS BY THE ENTERPRISE
}

\author{
Olena Koba*, PhD (Technical Sciences), Associate Professor, \\ Lyudmyla Svystun ${ }^{* *}$, PhD (Economics), Associate Professor \\ National University «Yuri Kondratyuk Poltava Polytechnic»
}

*ORCID 0000-0003-1914-3119

**ORCID 0000-0002-6472-9381

(C) Koba O., 2021.

(C) Svystun L., 2021.

Стаття отримана редакиією 27.02.2021 p.

The article received by the reduction 27.02.2021.

Introduction. The activity of any modern enterprise is difficult to imagine without the use of a car, and this requires the purchase of fuels and lubricants and proper organization of accounting for their movement. In the present circumstances it is particularly important efficient and economical use of any resources, including fuel, so the question becomes particularly relevant rational organization of accounting and control of fuels and lubricants entities.

Analysis of recent research sources and publications. The organization of accounting and control over the use of fuels and lubricants at the enterprise is the subject of research by many scientists in Ukraine. A significant contribution to the study of this issue was made by: A. Bazyliuk, M. Bazas, K. Bezverkhyi, H. Bykova, O. Bondarenko, F. Butynets, O. Vitkovska, O. Voloshyna, M. Holovin, R. Hrachova, Yo. Dankiv, V. Zakhozhai, M. Zinkovskyi, M. Korinko, N. Kokhtenko, S. Lukiantsova, V. Maksimova, O. Malyshkin, M. Matiukha, L. Mihunova, M. Ostapiuk, V. Palii, E. Sviderskyi, V. Sopko, V. Semenova, H. Sinitsa, O. Snisar, H. Titarenko, et al.

Some scientific works are devoted to studying the order of formation of the accounting policy of fuels and lubricants as a component of production stocks of the enterprise [1, 2].

Many publications of practicing accountants and consulting accountants in professional publications such as "Chief Accountant", "Debit-Credit", "All about accounting", "Accounting Week", "Taxes and Accounting", "Accountant 911", "Officially about Taxes", "Interactive Accounting", etc. cover the issues of accounting, taxation, control of operations related to the movement of fuels and lubricants at the enterprise $[3,45,6,7,8,9,10,11]$.

Scientists focus on studying the procedure for documenting operations with fuels and lubricants and its improvement.

Thus, I.O. Hladii, N.V. Kotseruba [12] exploring the theoretical foundations of documentation of operations with fuels and lubricants of the enterprise, propose to generalize information and strengthen control over the use of fuel coupons at the enterprise to apply a statement of coupons, which will increase the efficiency of management decisions in the process of economic activity.

Improving the documentation and clarifying the methodological principles of accounting for fuel purchased by the company on coupons and fuel cards is also the purpose by N.H. Zdyrko investigation [13]. Using the methods of analysis and synthesis, comparison and analogy, tabular method, modeling, the author proposed and substantiated an alternative option for documenting the receipt of fuel on the basis of the Act of acceptance of materials.

O. Varenyk, V. Marchenko [14] in order to improve the organization of accounting calculations with the use of fuel cards for fuel offer to account for fuel cards at cost on sub-account 112 "Low-value noncurrent tangible assets" with the establishment of liability for each card for the driver, in which it is constantly for use for its intended purpose, and not on account 22 "Low-value and perishable items". Funds of the enterprise on the accounts of the gas station network with access to them by fuel cards (both cash and "liter") - to be reflected in monetary terms on sub-account 371 "Settlements on advances issued", and not on sub-accounts 331 "Monetary documents in national currency" or 203 "Fuel". 
Problem and setting objectives. Despite the availability of research and publications, the theoretical and practical aspects of accounting and analytical support of operations with fuels and lubricants at the enterprise require further study. In particular, this applies to the formation of schemes of document flow operations with fuels and lubricants using different forms of calculations, which determines the choice of purpose and areas of research presented in this paper. The purpose of this study is to develop schemes for document flow of fuel and lubricants to the enterprise.

Results. The order of reception, transportation, storage, release and the account of fuels and lubricants at the enterprises and in the organizations of Ukraine of any form of ownership is regulated by the Instruction [15].

The organization of accounting and reflection of operations for the purchase of fuels and lubricants depends on the method of refueling: through stationary points on production sites of the enterprise; through third-party gas stations.

In any case, companies receive fuel and lubricants on the basis of agreements concluded with gas stations, which state:

- brand, type of fuel, its price (it can be either fixed for the entire volume, or actual on the day of refueling);

- when the ownership of fuel passes;

- method of receipt (coupons, plastic cards, fuel truck, etc.);

- place of receipt.

Documenting the refueling of road transport through stationary points at the production sites of your company is similar to the registration of the movement of inventories with the use of appropriate primary documents (Fig. 1).

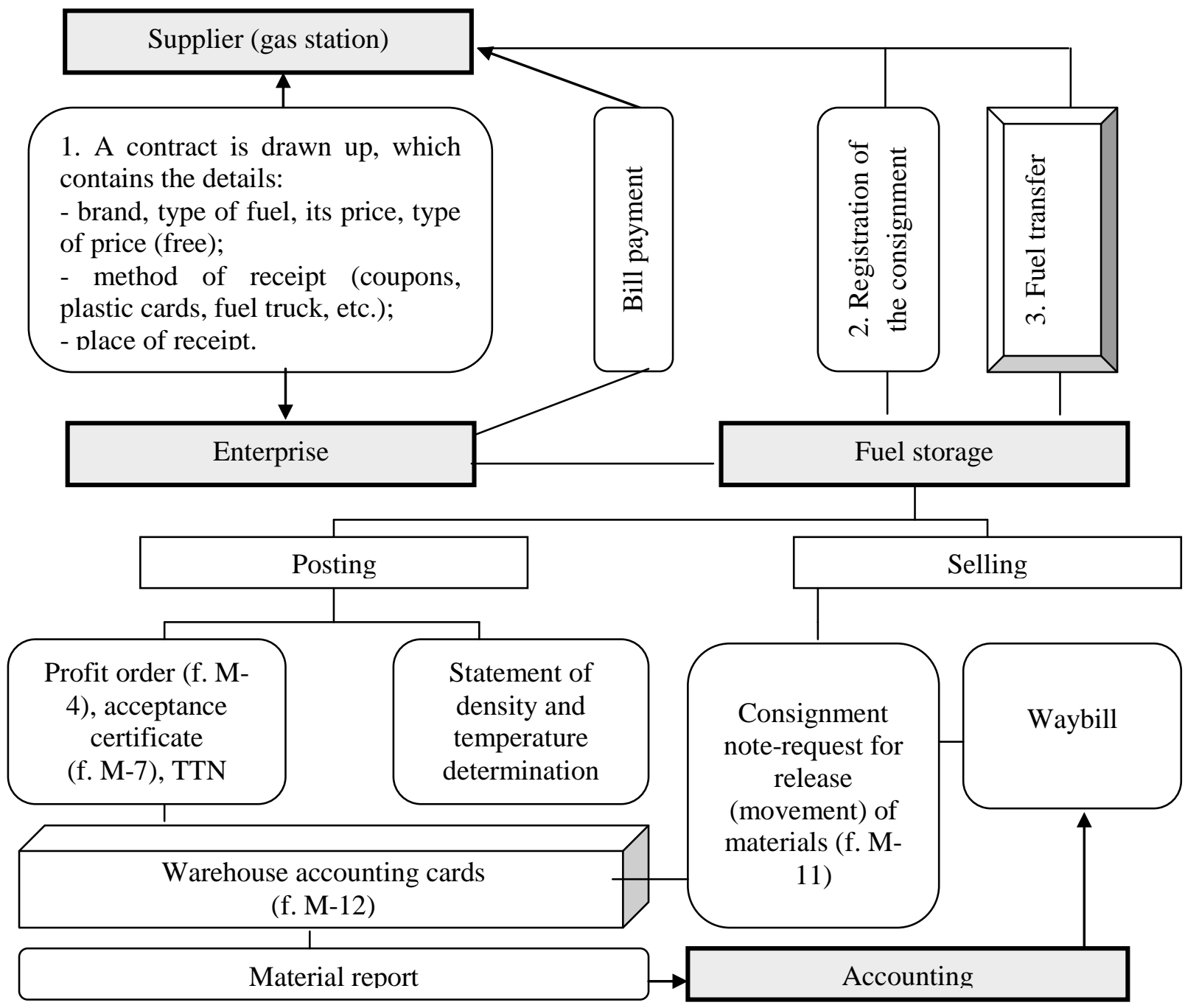

Fig. 1. The organization of acquisition of fuels and lubricants at gas station of automobile Source: [16] transport through stationary points on production sites of the enterprise 
Refueling of vehicles through third-party gas stations can be done non-cash and for cash.

Non-cash payments for fuels and lubricants can be made: without the use of coupons and with the use of: coupons and fuel cards.

When purchasing fuels and lubricants by cashless payment without the use of coupons, the document flow occurs in the following order (Fig. 2):

1. At the time of concluding a business agreement between the company and the gas station (or within a few days after its conclusion) in the statement of release of petroleum products fill in the following details: the name of the company and stamp, after which they are transferred to the gas station.

2. Make out the rest of the details of the information, which is made in two copies.

3. The gas station operator is obliged to put a stamp on the quantity of the released fuel in the statement and in the driver's waybill at release of fuels and lubricants according to the information. The statement can be filled in for several cars if they arrived at the gas station at the same time.

4. At the end of the month, the gas station transmits the second copy of the information to the company.

5. The accounting department of the gas station shall issue an invoice for the total cost of the issued fuel for the month, in which it shall indicate the name, quantity and cost by fuel brands. The data of the specified information the accounting department of the enterprise uses for display of receipt of fuels and lubricants in tanks of vehicles.

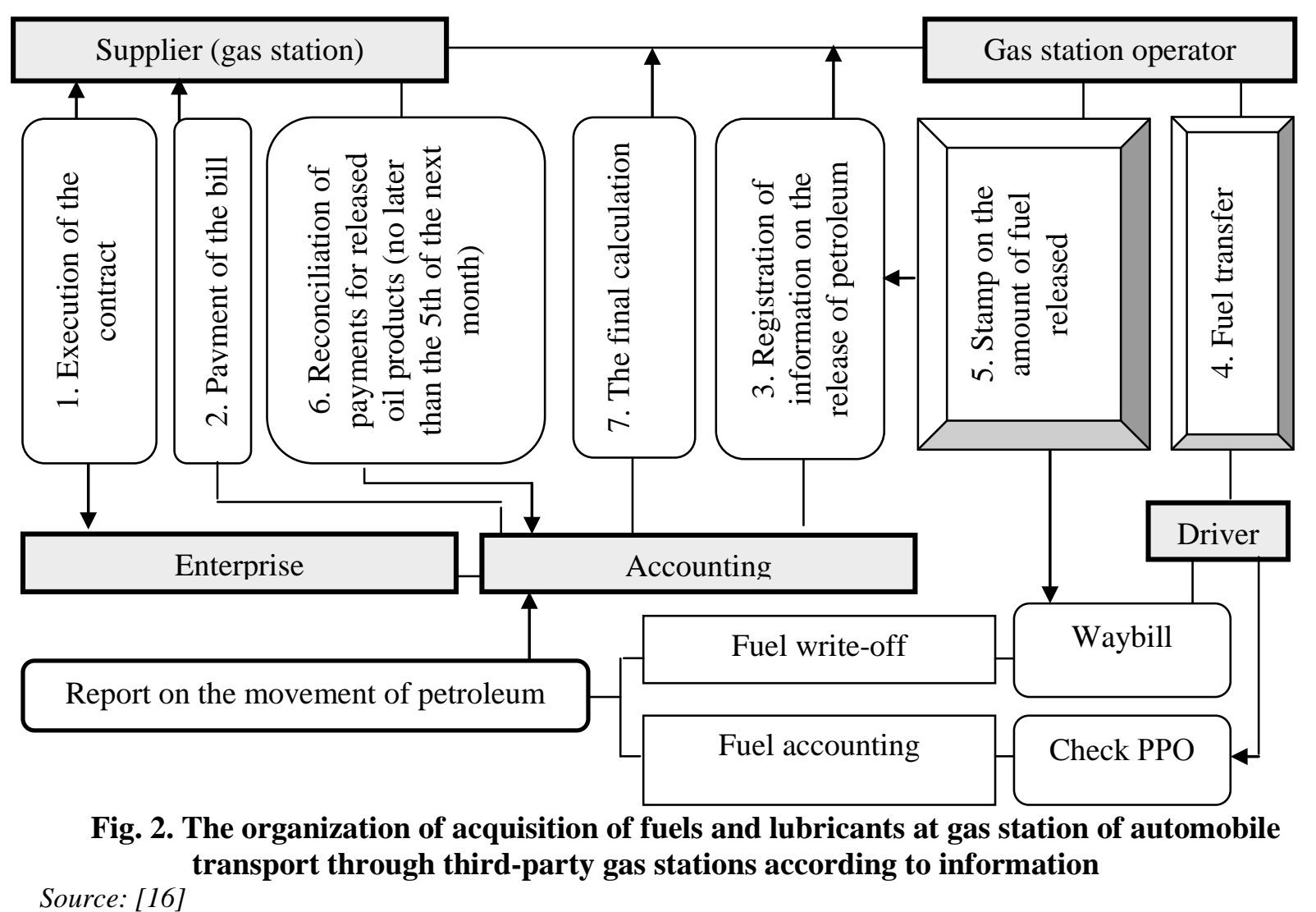

When refueling with coupons, the buyer company will purchase a certain number of coupons at the gas station, and then issue these coupons to drivers (Fig. 3). To do this, as in all other cases, a contract is concluded between the buyer of coupons and the gas station, which, in addition to other mandatory details, indicates the method of receipt - coupons. The contract also stipulates the validity of coupons, after which they can be exchanged for cash or other coupons. After concluding the contract, the buyer transfers the funds to the current account of the gas station within the time specified in the invoice.

Then the acceptance-transfer act is signed, on the basis of which the fuel and lubricants are transferred to the storage of the gas station. After fulfilling these conditions, the buyer is provided with fuel coupons. Coupons are issued to the driver, and he, when refueling the car at any of the gas stations specified in the 
previously concluded contract, exchanges them for the appropriate amount of fuel. The document confirming the use of coupons is a PPO check.

The driver provides it to the company's accounting department for fuel accounting.

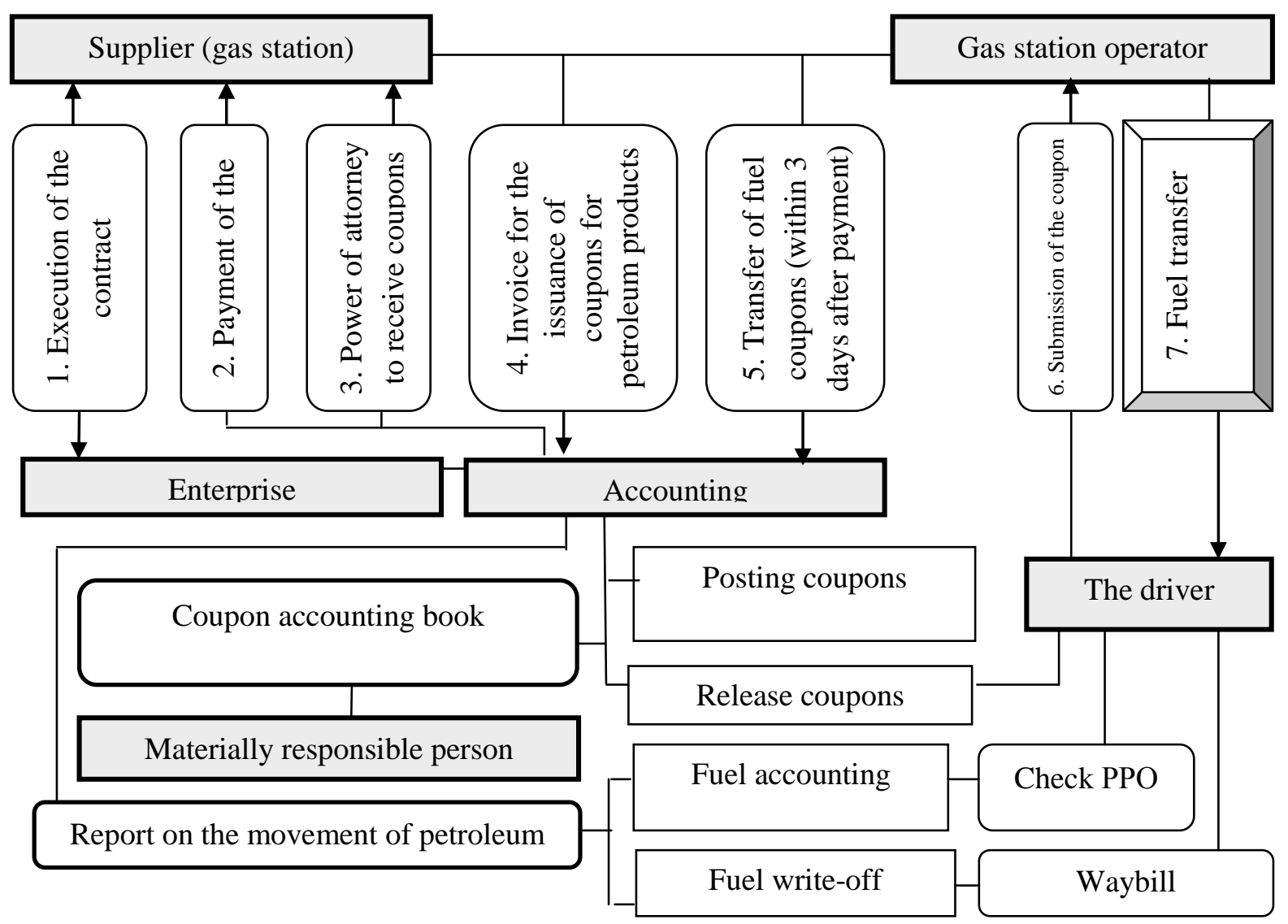

Fig. 3. Organization of purchase of fuels and lubricants at refueling of motor transport through

Source: [16] third-party gas stations on coupons

A characteristic feature of fuel coupons is the restriction of their validity for a certain period, for example, until the end of the current year (quarter, month). Therefore, the contract should provide for the exchange of unused coupons in the stipulated period for money or new coupons.

In the case of refueling with fuel cards after the conclusion of the contract, the company transfers the money, after which the gas station gives him one or more fuel cards. They are monetary and liter. When using cash fuel cards, a certain amount is transferred to a contingent account, and when receiving fuel, its value is usually deducted from the prices at the time of purchase. When using a liter card, the gas station credits to the conditional account not money, but the amount of fuel of a certain type (this is a feature of the fuel card) at the contract price (Fig. 4). The fuel card is stored in the accounting office, and in case of frequent use or long travel - assigned to the driver. To record the movement of fuel cards for drivers keep a book of records of the issuance of cards, and to record the movement of the card - a card for accounting of cash flows.

Recently, the option of purchasing fuel with a bank payment card is quite common. Specialized registrars of settlement operations at gas stations are equipped with payment terminals that can be connected or combined with the RRO. The bank payment card is a settlement card and does not require the conclusion of an agreement with the refueler, as when using fuel cards. The driver prepares a report on the use of funds issued under the report, and attaches to it checks of the payment terminal and RRO to confirm the transactions. 


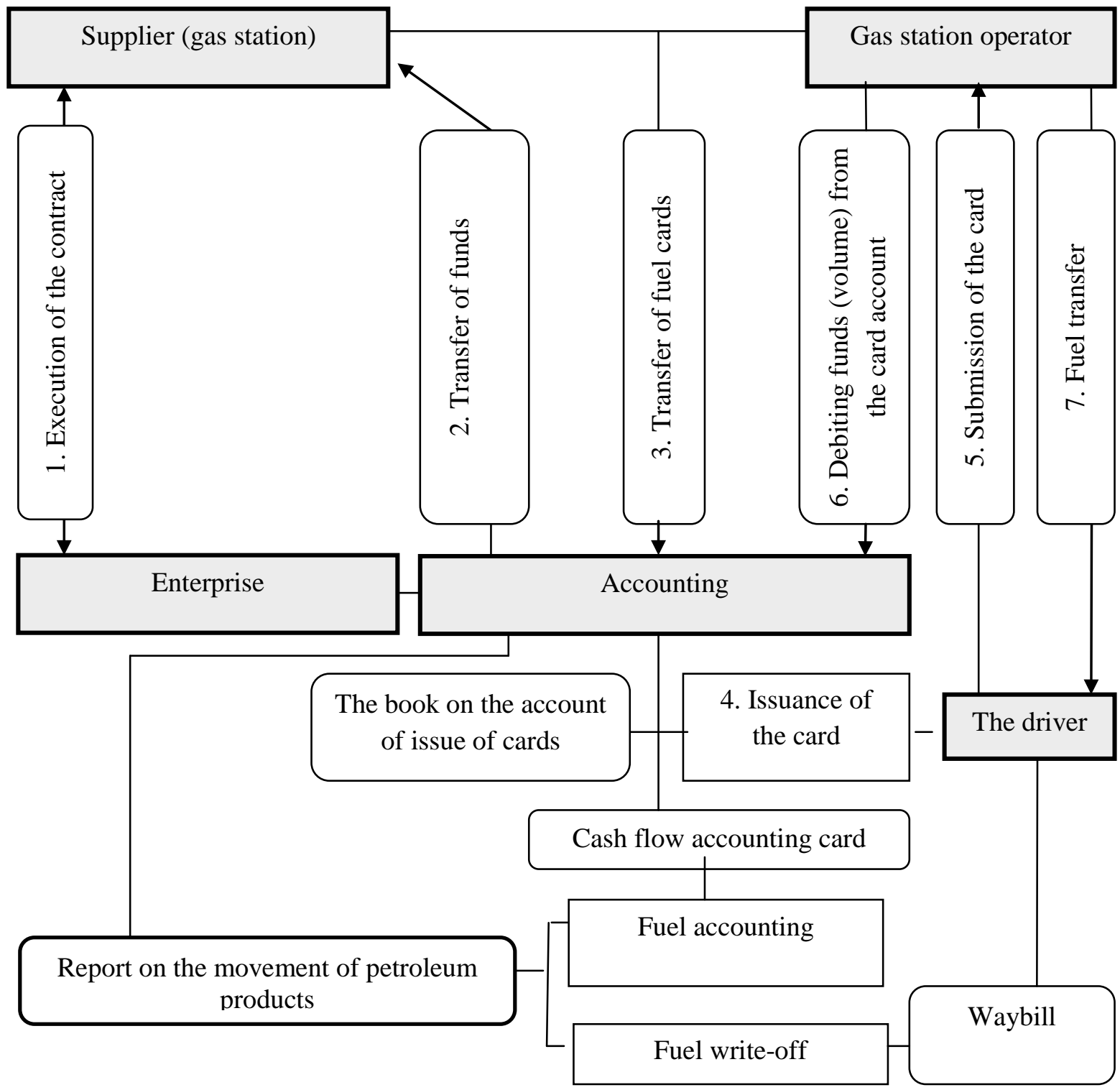

Fig. 4. Organization of purchase of fuels and lubricants at refueling of motor transport through third-party gas stations for non-cash payment with the use of fuel cards

Source: developed by the authors

The purchase of fuel and lubricants for cash is also accompanied by the preparation of such a report with the addition of a cash receipt at the gas station.

Conclusions and prospects. It is established that the implementation and reflection in the accounting of the purchase of fuels and lubricants is influenced by the method of refueling (through stationary points at the production sites of your company or through third-party gas stations) and the form of payment between buyer and supplier - gas station (cash or non-cash). The developed schemes of document circulation on operations on receipt of fuels and lubricants at refueling of motor transport through stationary points on production sites of the enterprise, through third-party gas stations for non-cash payment according to information, through third-party gas stations for non-cash payment according to coupons and fuel cards can be organization of accounting for fuels and lubricants at the enterprise.

\section{REFERENCES:}

1. Kravchenko, O. V., \& Pasternak, Ya. P. (2020), "Organization of the Primary Accounting of the Manufacturing Inventories and the Features of Their Reflection in the Accounting Policy of the Enterprise", Financial and Credit Activity: Problems of Theory and Practice, vol. 1, no. 3, pp. 77-83. doi: 10.18371/ fcaptp.v1i32.200330 
2. Lucchese, M., \& Carlo, F. Di (2020), "Inventories Accounting under US-GAAP and IFRS Standards", The Differences That Hinder the Full Convergence. International Journal of Business and Management, vol. 15, no. 7, pp. 180-195. doi: 10.5539/ijbm.v15n7p180. [in English].

3. Murashko T. (2016), "Purchase of fuel by cards", Ofitsiino pro podatky, no. 46 (903), available at: http://www.visnuk.com.ua/ ru/publication/100003579-pridbannya-palnogo-za-kartkami (Accessed 1.12.2020).

4. Karpova V. (2016), "Fuel at the enterprise”, Bukhhalterskyi tyzhden, no.17. available at: https://i.factor.ua/ukr/journals/bn/2016/april/issue-17/article-17408.html (Accessed 1.12.2020).

5. Olkhovyk O. (2019). "Refuel with coupons and fuel cards: what's on record?”, Podatky ta bukhhalterskyi oblik, no. 64(2292). pp. 10-13.

6. "Features of writing off fuel and lubricants on coupons" (2018), Interaktyvna bukhhalteriia, no 85. available at: https://interbuh.com.ua/ua/documents/oneanalytics/8402 (Accessed 1.12.2020).

7. Omelnytska Z. (2019), "Fuel accounting", available at: https://uteka.ua/ua/publication/commerce-12-xozyajstvennye-operacii-9-uchet-gsm (Accessed 1.12.2020).

8. Onyshchenko V. (2020), "Write-off of fuel at the enterprise", available at: https://www.golovbukh.ua/article/7625-spisannya-paliva-na-pdprimstv (Accessed 1.12.2020).

9. "Practical aspects of fuel accounting in the enterprise" (2019), available at: https://devisu.ua/uk/stattia/praktichni-aspekti-obliku-palnogo-na-pidprimstvi (Accessed 1.12.2020).

10. "Accounting for fuel and lubricants at the enterprise. How to automate the write-off of fuel and lubricants on waybills? (2019), available at: https://rubryka.com/2019/12/05/oblik-pmm-na-pidpryyemstvi/ (Accessed 1.12.2020).

11. Voronaia N, Nesterenko M., Chernyshova N. (2019), “Car operation”, Podatky ta bukhhalterskyi oblik, no. 67, available at: https://i.factor.ua/ukr/journals/nibu/2019/august/issue-67/article-66192.html (Accessed: 1.12.2020).

12. Varenyk O., Marchenko V. (2013, “Organization of accounting for fuel card payments”, Visnyk Berdianskoho universytetu menedzhmentu i biznesu, no. 4 (24), pp. 120-124.

13. Hladii I.O., Kotseruba N.V. (2018), "Features of documentation of accounting of fuels and lubricants”, Podilskii naukovyi visnyk, no. 4, pp. 34-41.

14. Zdyrko N.H. (2019), "Improving the methodological support of fuel accounting at the enterprise", Naukovyi visnyk Khersonskoho derzhavnoho universytetu, no. 35, pp. 111-118.

15. Ministry of Fuel and Energy of Ukraine, Ministry of Economy of Ukraine, Ministry of Transport and Communications of Ukraine, State Committee of Ukraine for Technical Regulation and Consumer Policy (2008), "Instruction on the procedure for receiving, transporting, storing, releasing and accounting for oil and oil products at enterprises and organizations of Ukraine: order of the Ministry of Fuel and Energy of Ukraine, Ministry of Economy of Ukraine, Ministry of Transport and Communications of Ukraine, State Committee of Ukraine for Technical Regulation and consumer policy of May 20, 2008 № 281” / available at: http://zakon0.rada.gov.ua/laws/show/z0805-08. (Accessed 1.12.2020).

16. Koba O. (2020), "Organization of fuel and lubricants accounting materials at the enterprise”, $A$ young scientist, $\quad$ no. 12, $\quad$ pp. 127-131, $\quad$ available file://C:/Users/Admin/Downloads/\%E2\%84\%9612(88)\%20-\%20online\%20(1).pdf

UDC 657.24

JEL: M41

Коба Олена Вікторівна, кандидат технічних наук, доцент. Свистун Людмила Анатоліївна, кандидат економічних наук, доцент. Національний університет «Полтавська політехніка імені Юрія Кондратюка». Документальне оформлення придбання паливно-мастильних матеріалів підприємством. Визначено порядок документального оформлення операцій з надходження паливномастильних матеріалів на підприємство внаслідок їх придбання через стаціонарні пункти на виробничих дільницях та через сторонні автозаправні станції з різними формами розрахунків. 3'ясовано, що підприємства отримують паливно-мастильні матеріали на підставі договорів, укладених з автозаправними станціями, де зазначається марка, вид пального, його ціна, момент переходу права власності, спосіб одержання, місце одержання пального. Установлено, що на здійснення і відображення в обліку придбання паливно-мастильних матеріалів впливає спосіб заправлення автомобільного транспорту: через автозаправні станції чи стаціонарні пункти на виробничих дільницях підприємства. Документальне оформлення заправлення автомобільного 
транспорту через стаціонарні пункти на виробничих дільницях підприємства відбувається подібно до оформлення руху виробничих запасів. Документальне оформлення заправлення автомобільного транспорту через автозаправні станції залежить від виду розрахунків (готівкою або безготівковим шляхом) та їх форми (відомості, талони, паливні картки). Придбання паливно-мастильних матеріалів за безготівковим розрахунком без використання талонів для відпуску палива на автозаправній станції відбувається за відомостями. Особливість відпуску палива за талонами полягає в обмеженні їх дії певним строком. Встановлено, що сучасним засобом розрахунків за придбане паливо $є$ літрові та грошові паливні картки, а також банківські платіжні картки. Розроблені схеми документообігу за операціями 3 надходження паливно-мастильних матеріалів при заправленні автомобільного транспорту через стаціонарні пункти на виробничих дільницях підприємства й через сторонні автозаправні станції у випадку використання відомостей, талонів, паливних грошових та літрових карток можуть бути використані для вдосконалення організації обліку паливно-мастильних матеріалів на підприємстві.

Ключові слюва: паливно-мастильні матеріали, талони, відомості, паливні картки, літрові картки, документальне оформлення обліку.

УДК 657.24

JEL: M41

Koba Olena, PhD (Technical Sciences), Associate Professor. Liudmyla Svystun, PhD (Economics), Associate Professor. National University "Yuri Kondratyuk Poltava Polytechnic". Documenting the Purchase of Fuels and Lubricants by the Enterprise. The order of documentation of operations on receipt of fuels and lubricants to the enterprise as a result of their acquisition through stationary points on production sites and through third-party gas stations with various forms of calculations is defined. It is found that companies receive fuel and lubricants on the basis of agreements concluded with gas stations, which indicate the brand, type of fuel, its price, the moment of transfer of ownership, method of receipt, place of receipt of fuel. It is established that the implementation and reflection in the accounting of the purchase of fuels and lubricants is influenced by the method of refueling - through gas stations or stationary points at the production sites of the enterprise. Documenting the refueling of motor vehicles through stationary points at the production sites of the enterprise is similar to the registration of the movement of inventories. Documenting the refueling of motor vehicles through gas stations depends on the type of payment (cash or non-cash) and their form (information, coupons, fuel cards). It is reported when purchasing fuel and lubricants by cashless payment without the use of coupons for the release of fuel at the gas station. The peculiarity of the release of fuel on coupons is the restriction of their validity for a certain period. It is established that the modern means of payment for purchased fuel are liter and cash fuel cards, as well as bank payment cards. The authors developed document flow schemes for operations on the receipt of fuel and lubricants when refueling vehicles through stationary points at the production sites of the enterprise and through third-party gas stations in the case of information, coupons, fuel cash and liter cards can be used to improve the accounting of fuel and lubricants at the enterprise.

Key words: fuels and lubricants, coupons, information, fuel cards, liter cards, documenting of accounting. 